to death. Results: The chewing and taste domains were serious problem following the recreation and activity domains. In the domains of speech and shoulder, patients ranked the more comfortable health states in each of these domains. The domains of mood and anxiety depended on social factors such as the condition of family who supported patients.

一ポスター展示発表一

$P-1$ ．九州歯科大学における OSCEトライアル 一概要と問題抽出一

○有田 正博·西田 郁子·吉野 賢一·小城 辰郎·中村 恵子·木尾 哲朗·大住 伴子·安細 敏弘

一田 利道·北村 知昭·坂本 英治·佐藤 耕一·篠原 雄二·庄野 庸雄·瀬田 祐司·園木 一男

芳賀 健輔·村田 貴俊·黑川 英雄·林田 裕·寺下 正道·横田 誠·西原 達次

九歯大·共用試験 OSCE 委員会

九州歯科大学においては，5年次生を対象に，第 1 回 OSCEトライアル（86 名）を 2003 年 3 月 15 日に, 第 2 回 OSCE トライアル (94 名)を 2003 年 12 月 6 日に実施した. 第 1 回目は 5 課題（医療面接,ブラッシング指導, ラバー ダム防湿, 概形印象採得, 単純抜歯), 第 2 回目は 7 課題 (医療面接, フィルムマウント, レジン充填, 根管治療, 支台歯形成，矯正装置の説明，バイタルサイン）であった．平均点は， 79.4 点および 80.4 点で概敉良好であった. 面 接·説明系課題と比較して技能系課題の平均得点率は低かった。また技能系課題においては試験場所および試験順序 の違いによる平均点の差が認められた.

\title{
Outline of the OSCE Trial in Kyushu Dental College
}

Masahiro Arita, Ikuko Nishida, Kenichi Yoshino, Tatsuro Kojo, Keiko Nakamura, Tetsuro Konoo, Tomoko Ohsumi, Toshihiro Ansai, Toshimichi Ichida, Chiaki Kitamura, Eiji Sakamoto, Kouichi Satoh, Yuji Shinohara, Yasuo Shono, Yuji Seta, Kazuo Sonoki, Kensuke Haga, Takatoshi Murata, Hideo Kurokawa, Yutaka Hayashida, Masamichi Terashita, Makoto Yokota and Tatsuji Nishihara (OSCE Executive Committee, Kyushu Dental College)

The OSCE Trials at Kyushu Dental College for 89 and 94 fifth year class students were performed twice on 15 March and 6 December, 2003. The first trial consisted of 5 stations (medical interview, instruction of tooth brushing, rubberdam dry field technique, alginate impression technique, tooth extraction). The second trial consisted of 7 stations (medical interview, dental X-ray film mount, filling of composite resin, root canal treatment, tooth preparation, explanation of the orthodontic appliance, check the vital sign). The average score was 79.4 point in first and 80.4 point in second trail. The average score in clinical skill was lower than that in the medical interview and explanation of the orthodontic appliance. The average score in clinical skill was affected by place and the order of the examination.

\section{$P-2$ ．第 1 回九州歯科大学共用試験歯学 OSCEトライアルの評価結果に対する評価者間の検討}

○坂本 英治·庄野 庸雄·吉野 賢一·木尾 哲朗·有田 正博·黒川 英雄·大住 伴子·北村 知昭 芳賀 健輔·中村 恵子·小城 辰郎·一田 利道·西田 郁子·佐藤 耕一·篠原 雄二·安細 敏弘 園木 一男·瀬田 祐司·村田 貴俊·林田 裕·寺下 正道·横田 誠·西原 達次

九歯大·共用試験 OSCE 委員会

Objective Structured Clinical Examination (OSCE) では評価の信頼性, 公平性が問題となってくる. 本格実 施を前に第 1 回九州歯科大学 OSCEトライアルが行われた。この結果から評価者間の公平性, 信頼性について検討を 行った. OSCEトライアルに参加した評価者 50 名の受験生に対する評価, 概略評価を各評価者間で比較した. ばらっ き具合を示す偏差平方和は技術系課題（抜菌 5.19 , ラバーダム 7.59 , ブラッシング指導 5.43 , 印象採得 6.40 ) に対し, 